- Programa Social e Ambiental dos Igarapés de Manaus - PROSAMIM - e seus impactos socioambientais sobre a qualidade de vida da comunidade do Parque Residencial Manaus

Dissertação de Mestrado

Dissertação apresentada ao Programa de Pósgraduação em Serviço Social da PUC-Rio como requisito parcial para obtenção do grau de Mestre em Serviço Social.

Orientador: Prof. Rafael Soares Gonçalves 
O Programa Social e Ambiental dos Igarapés de Manaus - PROSAMIM - e seus impactos socioambientais sobre a qualidade de vida da comunidade do Parque Residencial Manaus

Dissertação apresentada como requisito parcial para obtenção do grau de Mestre pelo Programa de PósGraduação em Serviço Social do Departamento de Serviço Social do Centro de Ciências Sociais da PUC-Rio. Aprovada pela Comissão Examinadora abaixo assinada.

Prof. Rafael Soares Gonçalves

Orientador

Departamento de Serviço Social - PUC-Rio

Profa. Valéria Pereira Bastos Departamento de Serviço Social - PUC-Rio

Profa. Maria de Fátima Cabral Marques

UFRJ

Profa. Mônica Herz

Vice-Decana de Pós-Graduação do Centro de Ciências Sociais - PUC-Rio

Rio de Janeiro, 28 de fevereiro de 2011 
Todos os direitos reservados. É proibida a reprodução total ou parcial do trabalho sem autorização da universidade, da autora e do orientador.

\section{Ana Lúcia Garrido}

Graduou-se em Pedagogia na Universidade Federal do Amazonas em 1994. Pós-graduada em Metodologia do Ensino Superior e Gestão de Instituições de Ensino Superior. Profissional da área da Educação desde 1979. Atualmente exerce a função de Coordenadora Administrativa de uma das unidades de ensino do Centro Universitário do Norte - UniNorte/Laureate International Universities.

Ficha Catalográfica

Garrido, Ana Lúcia

O Programa Social e Ambiental dos Igarapés de Manaus - PROSAMIM - e seus impactos socioambientais sobre a qualidade de vida da comunidade do Parque Residencial Manaus / Ana Lúcia Garrido; orientador: Rafael Soares Gonçalves. - 2011.

96 f. : il. (color.) ; $30 \mathrm{~cm}$

Dissertação (mestrado)-Pontifícia Universidade Católica do Rio de Janeiro, Departamento de Serviço Social, 2011 Inclui bibliografia.

1. Serviço social - Teses. 2. Ocupação dos igarapés. 3. PROSAMIM. 4. Impactos socioambientais. $\quad 5 . \quad$ Sustentabilidade socioambiental. 6. Qualidade de vida. I. Gonçalves, Rafael Soares. II. Pontifícia Universidade Católica do Rio de Janeiro. Departamento de Serviço Social. III. Título. 
Dedico este trabalho à minha família, como prova da minha eterna gratidão, pelo apoio, compreensão, respeito, solidariedade, carinho, enfim, pelo amor dedicado à minha pessoa. 


\section{Agradecimentos}

A Deus, por tudo.

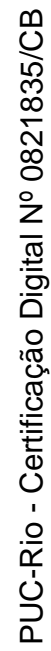

À minha família, pelo amor.

Ao Professor Doutor Rafael Soares Gonçalves, pelos ensinamentos, paciência, compreensão e respeito.

Às Instituições UniNorte/Laureate e PUC-Rio, na presença de seus professores, pelo incentivo e motivação.

À minha amiga Ana Flávia de Moraes Moraes pelo apoio logístico.

Às amigas Genilza, Leny, Darci e Izolda, por compartilharem as alegrias e as angústias.

Ao Prof. Waldery Areosa, pelas oportunidades.

À UGPI (Unidade de Gerenciamento do PROSAMIM), pela presteza das informações. 


\section{Resumo}

Garrido, Ana Lúcia; Gonçalves, Rafael Soares. O Programa Social e Ambiental dos Igarapés de Manaus - PROSAMIM - e seus impactos socioambientais sobre a qualidade de vida da comunidade do Parque Residencial Manaus. Rio de Janeiro, 2011. 96p. Dissertação de Mestrado - Departamento de Ciências Sociais, Pontifícia Universidade Católica do Rio de Janeiro.

O apogeu da borracha (década de 90, do século XIX) e a instalação da Zona Franca de Manaus (1967), apesar de favorecerem o crescimento da cidade, intensificaram um passivo social, pois Manaus não apresentava uma infraestrutura urbana compatível com a demanda da imigração. Com isso, os entornos dos igarapés começaram a ser ocupados de forma desordenada, ocasionando sérios problemas ambientais e comprometendo a qualidade de vida dos ocupantes dessas áreas. Visando resolver as questões relacionadas a essas problemáticas, o Governo do Estado do Amazonas desenvolveu, a partir de 2003, o PROSAMIM (Programa Social e Ambiental dos Igarapés de Manaus). Esta iniciativa converteu-se em motivação para a realização desta pesquisa, pois pretendeu-se identificar quais foram os impactos socioambientais do PROSAMIM, estabelecer a relação entre sustentabilidade socioambiental e qualidade de vida e caracterizar o conceito de qualidade de vida a partir da percepção dos moradores da comunidade pesquisada. A partir dessas pretensões, esta pesquisa foi, quanto aos meios, uma pesquisa documental e para se obter outros dados, adotou-se a entrevista do tipo estruturada e a aplicação de um questionário do tipo fechado e estruturado. A pesquisa admite que o PROSAMIM proporcionou melhorias na vida dos moradores, integrando de forma significativa as áreas de intervenção do programa à cidade, alterando de forma intensa a paisagem urbana ao, por exemplo, reassentar as famílias em um ambiente requalificado.

\section{Palavras-chave}

Ocupação dos igarapés; PROSAMIM; impactos socioambientais; sustentabilidade socioambiental; qualidade de vida. 


\section{Abstract}

Garrido, Ana Lúcia. The Social and Environmental Program of the streams of Manaus - PROSAMIM - and their environmental impacts on quality of life of the community of Parque Residencial Manaus. Rio de Janeiro, 2011. 96p. MSc. Dissertation - Departamento de Ciências Sociais, Pontifícia Universidade Católica do Rio de Janeiro.

The heyday of the rubber (90s, nineteenth century) and the installation of the Manaus Free Zone (1967), while favoring the growth of the city, have intensified a social liability, since Manaus was not in an urban infrastructure compatible with the demand immigration. Thus, the surroundings of the streams began to be occupied in a disordered fashion, leading to serious environmental problems affecting the quality of life for occupants of these areas. Aimed at resolving issues related to these problems, the Government of the State of Amazonas developed, from 2003, PROSAMIM (Social and Environmental Program of the streams of Manaus). This initiative has become a motivation for this research because we sought to identify what were the social and environmental impacts of PROSAMIM establish the relationship between social and environmental sustainability and quality of life and to characterize the concept of quality of life from the perception of the residents from the researched community. From these claims, this research was, as to the means, the document retrieval and to obtain other data, we adopted the type of structured interview and the application of a closed-type questionnaire and structured. The study acknowledges that the PROSAMIM provided improvements in the lives of residents, incorporating significantly the areas of intervention programs to the city, changing the intensely urban landscape by, for example, resettling families in an environment reclassified.

\section{Palavras-chave}

Occupation of the streams; PROSAMIM; environmental impacts, social and environmental sustainability, quality of life. 


\section{Sumário}

1. Introdução 14

2. A cidade de Manaus e o projeto PROSAMIM

2.1. O crescimento da cidade de Manaus e a ocupação dos igarapés

2.2. O Programa Social e Ambiental dos Igarapés

de Manaus - PROSAMIM

3. O PROSAMIM e a Qualidade de Vida

3.1. Percepções sobre qualidade de vida no Parque

Residencial Manaus

3.2. Impactos socioambientais e qualidade de vida no

Parque Residencial Manaus

56

4. O PROSAMIM e a sustentabilidade social

63

4.1. A gestão de cidades e a sustentabilidade

63

4.2. Programas de sustentabilidade social no Parque

Residencial Manaus

71

5. Conclusão

80

6. Referências

83

7. Anexos

89 


\section{Lista de Figuras}

Figura 1- Habitações populares nas margens e leitos dos igarapés

Figura 2- Habitações populares nas margens e leitos dos igarapés

Figura 3- Articulação institucional do PROSAMIM

Figura 4- Estudos, Planos e Projetos do PROSAMIM

Figura 5- Moradia padrão construída pelo PROSAMIM

Figura 6- Moradia padrão construída pelo PROSAMIM

Figura 7- Área de abrangência das obras do PROSAMIM 36

Figura 8- Habitações populares em locais inadequados 39

Figura 9- Habitações populares em locais inadequados 40

Figura 10- Condição de sub-moradia

Figura 11- Acúmulo de lixo nas margens e leitos dos

igarapés 


\section{Lista de Tabelas}

Tabela 1 - Tempo de moradia nas palafitas antes do PROSAMIM

Tabela 2 - Principal mudança na vida proporcionada pelo

PROSAMIM

Tabela 3 - Item que mais proporciona bem estar na nova moradia

Tabela 4 - Maior problema quando morava próximo ao

igarapé

Tabela 5 - Doenças mais freqüentes na área antes do

PROSAMIM

Tabela 6 - As causas das doenças

Tabela 7 - Serviço essencial para os beneficiados pelo

PROSAMIM

Tabela 8 - Serviço que facilitaria a convivência comunitária 


\section{Lista de Gráficos}

Gráfico 1- Tempo de moradia nas palafitas antes do PROSAMIM

Gráfico 2- Principal mudança proporcionada

pelo PROSAMIM

Gráfico 3- Item que mais proporciona bem estar na nova

moradia

Gráfico 4- Maior problema quando morava próximo ao

igarapé

Gráfico 5- Doenças mais freqüentes na área antes do

PROSAMIM

Gráfico 6- As causas das doenças

Gráfico 7- Serviço essencial para os beneficiados pelo

PROSAMIM

46

Gráfico 8- Serviço que facilitaria a convivência comunitária 


\section{Lista de Quadros}

Quadro 1- Aspectos gerais da população

Quadro 2- Impacto ambiental evitado

Quadro 3- PROSAMIM - Melhoria ambiental, urbanística e Habitacional

Quadro 4- Metas para o desenvolvimento do PROSAMIM 
Aprenda como se você fosse viver para sempre; viva como se fosse morrer amanhã.

Anônimo 